\title{
Euskal kooperatiben gardentasun publikoa: aurrerapausoak eta erronkak
}

\author{
Itxaso Gallastegi Ormaetxea \\ Eusko Jaurlaritzako Bekadun Predoktorala eta Deustuko Unibertsitateko «Kooperatibismoa, \\ fiskalitatea, lan-harremanak eta babes soziala» Ikerketa-taldeko laguntzailea
}

Aurkibidea: I. Sarrera. II. Gardentasun publikoaren araubide berriek kooperatibengan duten eraginaren interpretazio bat. a) Estatu maila: 19/2013 Legea, gardentasunari, informazio publikoa eskuratzeko bideari eta gobernu onari buruzkoa. b) Autonomia Erkidego maila: Estatuko Legeaz haratago. III. Kooperatiben gardentasun publikoa sendotzeko zenbait euskal ekimen. a) Euskal Sektore Publikoaren Gardentasunaren, Herritarren Parte-hartzearen eta Gobernu Onaren Lege Proiektua. b) Gipuzkoa eta Bizkaiko Aldundien gardentasunaren foru arau berriak: aipamen laburra. c) Gardentasunak egungo kooperatiba-legerian duen tokiaren gogoeta. IV. Gardentasun publikoarekiko euskal kooperatiben konpromisoaren garrantzia. V. bibliografia. VI. Legeria iturriak

Laburpena: Kooperatibek egungo sistema kapitalistak eragindako krisi globalaren ondoreei aurre egiteko alternatiba egokia eratzen dute gurean. Hala uste du, behintzat, hainbat adituk, larriagotutako bazterketa-esparruak betetzeko eta kolokan jarritako zerbitzu publikoen prestazioa ontzeko gaitasunak izan badituztela argudiatuz. Herritarrek ere ideia horren alde egin dezaten, baina, kooperatibek nahitaezko dute jeneralki gauzatutako jardun justu eta arduratsuaren berri ematera pasatzea, gardentasun publikoaren desafioa, bere garrantziaz jabetu ez izateagatik beharbada, alboratuta izan baitute. Hori dela eta, Espainiako zein berorren Autonomia Erkidegoetako ekimen legegile ezberdinetatik abiatuz, euskal kooperatibek gardentasunaren alorrean izan ditzaketen betebeharrak aztertuko ditu artikulu honek. Izan ere, sumatzen zaizkien zehaztugabetasun eta hutsuneak medio, argi dago marko estrategiko espezifiko baten prestatzeari ekin beharko litzaiokeela, kooperatibek eurek hartu beharreko gardentasunaren aldeko konpromisoa ahaztu gabe.

Hitz gakoak: Euskal kooperatibak; alternatiba; gardentasun publikoaren desafioa; marko estrategiko espezifiko bat; konpromisoa.

Resumen: Las cooperativas constituyen la alternativa óptima en nuestra Comunidad para combatir las consecuencias de la crisis global, fruto del sistema capitalista imperante. Eso creen, al menos, varios expertos, argumentando que disponen de capacidades para llenar los espacios de exclusión que 
se han visto agravados y mejorar la prestación de aquellos servicios públicos comprometidos por la misma. Empero, en aras de que los ciudadanos también apoyen dicha idea, las cooperativas deben pasar a exponer el ejercicio que han desarrollado, generalmente, de forma justa y responsable, ya que, por no haber sido conscientes de su importancia quizá, el desafío por la transparencia pública ha ocupado un segundo plano en su seno.

Así pues, partiendo de las iniciativas legislativas estatal y autonómicas, el presente artículo analiza las obligaciones que las cooperativas vascas podrían tener en el ámbito de la transparencia. Y es que las imprecisiones y lagunas que se aprecian al respecto evidencian la necesidad de confeccionar un marco estratégico específico, sin olvidar, eso sí, el compromiso que las propias cooperativas deben asumir.

Palabras clave: Cooperativas vascas; alternativa; desafío de la transparencia pública; marco estratégico específico; compromiso.

Abstract: Cooperatives are the best alternative in our community to fight the consequences of the global crisis, prevailing capitalist system's result. At least, some experts believe it, arguing that they are able to both fill the exclusion spaces that have been aggravated and improve the delivery of public services compromised by it. However, for having citizens' support too, cooperatives should start proving that their usual practices are as fair as responsible, because, perhaps, for not have been aware of its importance, the challenge of public transparency has taken second place in their midst.

Thus, basing on the state and regional legislative initiatives, this paper analyzes the obligations the Basque cooperatives could have on transparency's area. In fact, the inaccuracies and gaps that can be seen about state the need to implement a specific strategic framework, taking always into account the compromise that cooperatives themselves must assume.

Keywords: Basque cooperatives; alternative; the challenge of public transparency; specific strategic framework; commitment. 


\section{Sarrera}

Gardentasunak sozietate kooperatiboen funtzionamendu onaren giltzarrietako bat eratzen du. Izan ere, FAJARDO GARCíAk adierazi duen bezala, «kooperatibak autolaguntza, autoerantzukizun, demokrazia, berdintasun, zuzentasun eta solidaritate balioetan oinarritzen» diren bitartean, bazkideek gardentasun, onestasun eta erantzukizun zein bokazio sozialaren balore etikoak bere egiten dituzte ${ }^{1}$. Bada, euren izaerak berak, euren jarduna gidatzen duten printzipioekin bat, duten antolaketa, asmo nahiz aktibitateari buruzko informazioa helarazteko zeregina ezartzen duela esan daiteke. Eta horrek, kooperatibismoa herritarren ongizate mailaren hobekuntzarako alternatibatzat dugun asko, kudeaketa-eredu gardenak galdatzera garamatza.

Lorpen kooperatiborik falta ez den arren, GADEA solERrek ongi ohartarazi du «mugimendu kooperatiboak egungo munduaren arazoei aurre egiteko kooperatibak instrumentu egokia direla bistaratzeko esfortzu nahikoa egin duen edota helburu hori erdietsi duen beste kontu bat» dela ${ }^{2}$. Beste era batera esanda, nahiz eta erakunde hauen organizazioa eta administrazioa jeneralean behar bezalakoak izan, herritarren konfiantza berreskuratzeak —edo berreraikitzeak, gurago bada- jokabide arduratsu horren berri ematera pasatzea eskatzen diela, efektibotasunez eta ahalik eta arinen. Arrazoia? Hamaika aktore publikoren azken urteotako praktika ustelek, beste sektoreetako zenbait agenteren parte-hartze eta konplizitatearekin uztartzeagatik askotan, merkatuko alor guztietan izan dituztela ondorioak, baita ekonomia sozialaren esparruan ere. Eta hortaz, fidagaiztasun horrek, berez kooperatibenganakoa ez izanagatik, barne hartu dituela, bai hauen aritzea, bai hauen gaitasunak.

Ezinbestekoa da, orduan, kooperatibek gardentasun publikoaren aldeko apustu tinko bat egitea. Hasteko, legez ezarritako betebehar materialei erantzun beharko diete, gainontzeko eremuetan jazotzen ari den gisara. Baina hauengandik bereiztea beraien esku egongo da, borondatezko ekintzez baliatzeak betidaniko apartekotasunari eusteko aukera emango bailieke.

1 Fajardo García, Isabel-Gemma. "La especificidad de las sociedades cooperativas frente a las sociedades mercantiles y la legitimidad de su particular régimen jurídico y fiscal según el Tribunal de Justicia de la Unión Europea». Revista de Derecho Mercantil, 288. zk., 2013, 200. or.

2 GADEA SOler, Enrique. «Difusión de valores y principios cooperativos entre los jóvenes». In: Arnáez ArCe, Vega María (Coord.). Difusión de los valores y principios cooperativos entre la juventud. Dykinson, Madril, 2015, 137. or. 
Horiek horrela, jarraikako lerroek Espainian zein berori osatzen duten Autonomia Erkidegoetan oraintsu onartutako gardentasun araudiek kooperatibengan izan dezaketen eragina izango dute abiapuntu. Euskal kooperatiben gardentasun publikoa sustatzeko ekimenen azterketa jasoko dute segidan, bere errotzea posible egingo lukeen geure kooperatibek eurek hartu beharreko konpromisotik eratortzen den lanaren inguruko proposamen xume batekin bukatzeko.

\section{Gardentasun publikoaren araubide berriek kooperatibengan duten eraginaren interpretazio bat}

Kooperatibei gardentasunaren desafioa gainera etorri bazaie, euren erregulazioaren

kargudunak ere ezustean harrapatu dituela pentsatuko du batek baino gehiagok, eta tamalez, hala izan da. Adituen eskakizunetako bat, hain justu, gardentasun publikoaren lege berrien behin betiko testuen aplikazio-esparru subjektiboek izaera publikorik gabeko erakundeak ere baitaratu ditzaten izan da -baldintza batzuk betetakoan behintzat- . Eta horren ondorioz, beharturiko sarrera baten aurrean gaudelako ustea agertu da, gehienetan eraginkortasun falta nabari baten eskutik doana.

Iritzi hori aintzat hartuz, datozen atalak kooperatibei gardentasunaren marko juridiko egin berriek eskainitako lekua zehazten saiatuko dira, eta egokia ez balitz, izan beharko luketena planteatzen.

a) Estatu maila: 19/2013 Legea, gardentasunari, informazio publikoa eskuratzeko bideari eta gobernu onari buruzkoa

2013ko abenduaren 9an 19/2013 Legea, gardentasunari, informazio publikoa eskuratzeko bideari eta gobernu onari buruzkoa ${ }^{3}$, onartu zuen Espainiak. Ordura arte gaiaren inguruko arauketarik gabeko Europar Batasuneko Estatu bakanetakoa izan zen —Luxemburgo, Malta eta Txiprerekin batera-, gardentasun-adierazle nagusiek behin baino gehiagotan adierazi ziotelarik gutxieneko estandarrik gabeko egoera biziki larri horrekin bukatzeko zuen premia.

3 Espainia. 19/2013 Legea, abenduaren 9koa, gardentasunari, informazio publikoa eskuratzeko bideari eta gobernu onari buruzkoa. Estatuko Aldizkari Ofiziala, 2013ko abenduaren 10a, 295. zk.aren euskarazko gehigarria, I. at., 1. or. 
Legeak aipatu hutsunea betetzea lortu badu ere, eta berorren azterketa orokor bat gauzatzeak lan honen helburua gaindituko lukeela jakinda, oinarrizko zenbait akats aurkezten dituela esan beharra dago, besteak beste: objektu zatikor bat; lege arrunt moduan tramitatu izana, informazio publikoa eskuratzeko sarbide eskubideari izaera ius fundamentalik aitortu gabe; azken honi jarritako muga zehaztugabeak; bere jardute elektronikoaren garapen urria; isiltasun administratibo bikoitz baten ezarpena; edota jasotzen dituen betebeharren betepenaren ikuskaritza- eta kontrol-organoari sumatzen zaion independentzia eza4 Eta oker guzti horiei aplikazio-eremu subjektibo osagabe baten finkapena gaineratzen zaie, bereziki inportantea dena hemen.

Hasiera batean espainiar legegileak instituzio publikoei soilki zuzendutako lege proiektua plazaratu zuen arren, egia da beste motatako hainbat erakunde ere barne hartu dituela bere azken bertsioak ${ }^{5}$. Horrela, Administrazio Publiko guztiak, Botere Legegile eta Judizialaren organoak eta hainbat entitate konstituzional eta estatutario obligarazteaz gain, bere aginduak garrantzi publikoa duten edota fondo publikoen hartzaile diren zenbait erakunde ukitzera pasatu dira, Administrazio Zuzenbideko jarduerei dagokienean. Horien adibide dira Espainiako Bankua eta Errege Etxea 6 .

Ez hori bakarrik. Legearen 3. artikuluak alderdi politiko, sindikatu eta enpresa-erakundeak, alde batetik, eta laguntza edo subentzio publikoetatik eratorritako kopuru jakinen onuradun pribatuak, bestetik, baitaratu ditu. Bigarren kasuan, zehatzago, irizpide bi ipini ditu: urtebetez 100.000 euro baino gehiago jasotzea edo gutxienez urteko sarreren \%40a, 5.000 euroko minimoarekin. Eta hona hemen gakoa, konexio-puntu hauen araberakoa baita kooperatiben 19/2013 Legearen manuenganako menpekotasuna. Alegia, euren izaera juridikoak baino, kasuan kasu azaltzen dituzten ezaugarriek erabakitzen dutela Legearen aplikazio-esparru subjektiboan dauden ala ez.

Nolanahi ere, aurrerapauso hauen mugez konturatzea ezinbestekoa da. BLANES CLIMENTen hitzetan, «[...]demokrazia baten, herritarrek publikoak edota interes orokorrekoak diren gaiei buruzko informaziora

${ }^{4}$ Analisi zehatz bat ezagutzeko, ikus: «Comentarios a la nueva regulación de la transparencia pública en España». Administración de Andalucía: Revista Andaluza de Administración Pública, 89. zk., 2014, 379-409. or.

${ }^{5}$ Askorentzat bere I. Kapituluko I. Tituluan jasotako hau da lege proiektuarekin alderatuz agertzen duen aldaketarik esanguratsuena. Ikus, adibidez: GuICHOT REINA, Emilio. Transparencia y Buen Gobierno. Estudio y Ley. Thomson Reuteurs, Zizur Txikia, 2014, 15-18. or.

6 Alabaina, jakina denez, Errege Etxeak ez dauka botere legegile edo judizialik, eta beraz, bere egintza orori erreferentzia egiteak zuzenena zirudien. Ideia hau azken talde horretako erakunde gehienen jardutearekin lotu daiteke gainera. 
sarbidea izateko eskubidea izan badute, momentu bakoitzean informazio hori duen entitatearen estatutu juridikoa publikoa edo pribatua den alde batera utzita. Eta entitate publiko edo pribatu horiek, informazio horren izate hutsagatik, modu aktiboan helaraztera behartuta daude, euren web orrialdeen bitartez» ${ }^{7}$. 3. artikuluak, ordea, publizitate aktiboari buruzko I. Tituluko II. Kapituluko xedapenak betetzera baino ez ditu derrigortu jasotako subjektuak, bere posizioa gainontzeko obligaziodunenenarekin parekatzeko okasioa galduz ${ }^{8}$. Eta horri 5.4. artikuluaren bigarren paragrafoak zera erantsi dio: "Interes sozial edo kulturaleko xedea besterik ez duten irabazi-asmorik gabeko entitateak badira eta 50.000 euro baino gutxiagoko aurrekontua badute, entitate horri laguntza edo diru-laguntza publiko gehien ematen dizkion Administrazio Publikoak eskura jarritako bitarteko elektronikoen bidez bete ahal izango dira lege honetan ezarritako betebeharrak» ${ }^{9}$.

Adierazitakoez bestelakoak diren eta zerbitzu publikoak ematen dituzten edo administrazio-ahalak dauzkaten pertsona fisiko eta juridikoei ondorengo zeregina ezarri die 4. artikuluak: hala eskatutakoan, atxikita dauden Administrazio Publiko, organismo edo erakundeei beren eginbeharren betepenerako beharrezko duten informazioa ematea. Obligazio horren norainokoa ez du zehaztu, baina. Sektore publikoko kontratuen adjudikaziodunei begira, gainera, kontratuan aurreikusitako baldintzetan bakarrik zabaldu du. Horrek, oLmEDO PALACIosen ustez, «bereziki sentikorra den gai batean akordio indargabetzaileei atea zabalik uztea» dakar ${ }^{10}$, GUICHOT REINArentzat ere arrazoigabekoa dena ${ }^{11}$. FERNÁNDEZ RAMOsek, haatik, argitzat jo du «kontratuak ezin duela publi-

7 Blanes Climent, Miguel Ángel. La transparencia informativa de las Administraciones Públicas. El derecho de las personas a saber y la obligación de difundir información pública de forma activa. Thomson Reuteurs, Zizur Txikia, 2014, 89. or.

8 Jakin 2. artikuluko subjektuek —atal honetako 3. paragrafoan aitatutakoak- publizitate aktiboaren betebeharrei erantzuteaz gain, informazio publikora sarbidea izateko duten eskubidearen baitan herritarrek eskatutako informazioa helarazi behar dutela - Legearen I. Tituluaren III. Kapitulua-.

9 Dena den, Fernández Ramosek ongi azaldu duenez, azken mandatu honen «funtsezko intentzioak argia dirudi, gardentasun-betebeharrek irabazi-asmorik gabeko entitateei gehiegizko karga burokratiko bat suposatzea ekiditeko zentzuan[...]». FeRNÁNDEZ RAMOS, Severiano. "Transparencia y Acceso a la Información Pública». In: Fernández Ramos, Severiano eta Pérez Monguió, José María, Transparencia, Acceso a la Información Pública y Buen Gobierno. Ley 19/2013, de 9 de diciembre. Thomson Reuteurs, Zizur Txikia, 2014, 99. or.

10 Olmedo Palacios, Manuel. «La Ley 19/2013, de 9 de diciembre, de transparencia, acceso a la información y buen gobierno». Diario La Ley, 8237. zk., 2014, 4. or.

11 Guichot Reina, Emilio. Transparencia y Buen Gobierno. Estudio y Ley, op. cit., 17-18. or. 
zitate betebehar legala baztertu, gehienez bere betepenaren alderdi osagarriak modulatu baizik» ${ }^{12}$. Edozein kasutan, lan honen muinari dagokionean, nahiz eta 3. artikuluko irizpideak ez bete, kontratistak diren kooperatibak Legeari lotuta egongo direla ondoriozta daiteke ${ }^{13}$.

Eta bukatzeko, doktrinaren zein gizartearen parte handi baten eskariei entzungor eginez, espainiar legegileak presio taldeen edo lobbien jarduera ukitu ez izanari egin behar zaio erreferentzia.

Bada, aipatu kasuetan tokitutako kooperatibei Legeak jarritako publizitate aktiboko betebeharrak identifikatzera pasatuko gara orain, hots, eskaera konkreturik itxaron gabe, beren kasa helarazi beharreko informazioa zehaztatzera. Izan ere, arauaren literaltasunak zein izaerak berak 6-8 artikuluetako obligazio material guztiekin konplitu beharrik ez dutela ulertarazten dute.

6. artikulua, erakunde-, antolamendu- eta plangintza-informazioari buruzkoa, bi zatitan banatzen da: lehenengoak badu kooperatibengan eraginik, Legeak jasotako subjektu guztiei jartzen baitie betetzen dituzten funtzioen, aplikatu beharreko araudiaren eta antolamenduegituraren inguruko informazioa publikatzeko zeregina, "horretarako, organoetako arduradunak eta haien profila eta ibilbide profesionala jasotzen dituen organigrama eguneratua argitaratuz». Halere, kooperatibak arauaren aplikazio-eremu subjektiboan sartzeko legegileak jarraitutako irizpidearekin bat etorriz, hau da, publikoki finantzatutako aktibitateak burutzen dituen subjektu orok horien inguruko kontuak ematearekin, manua, «betetzen dituzten funtzioak» izendatzean, finantziazio publikoari esker gauzatutako ekintzei buruz baino ez dela ari interpreta daiteke. Bigarren atala, bestalde, Administrazio Publikoei bakarrik zuzentzen da. Eta motibo berberak askatzen ditu, hain zuzen, organismo hauek 7. artikuluaren, garrantzi juridikoko informazioari buruzkoaren, betebeharretatik.

Azkenik, 8.1. artikuluak obligaziodun orok plazaratu beharreko ekonomian edo aurrekontuan eragina duten administrazio-kudeaketako zenbait egintza zerrendatzen ditu. Lehenengotan kooperatibek a), b) eta c) puntuek hurrenez hurren bildutako kontratu, hitzarmen eta su-

12 Fernández Ramos, Severiano. «El ámbito subjetivo de la normativa sobre transparencia del sector público. Problemas y disfunciones». In: Valero Torrijos, Julián eta FerNÁNDEZ SALMERÓN, Manuel (Koord.). Régimen jurídico de la transparencia del sector público. Del derecho de acceso a la reutilización de la información. Thomson Reuteurs, Zizur Txikia, 2014, 127. or.

13 Artikulu biek jasotakoa betez gero, ostera, 3. artikuluaren menpe ulertu beharko lirateke, manu zorrotzagoa baita bere jarrera proaktiboari, eta beraz, bere jardueraren gardentasunari — Legearen asmo nagusia dena- begira. 
bentzio zein laguntza publikoen informazioa helarazteko egitekoa dutela pentsa badaiteke ere, artikuluaren bigarren atalak zehaztu egin du gai horiek 3. artikuluko subjektuekin duten harreman konkretua. Hortaz, kontutan izan kooperatibek paragrafo horietako eskakizunak Administrazio Publikoekin sinatutako kontratu edo hitzarmenak direnean edo horiek emandako laguntzak direnean baino ez dituztela bete behar —eta jakina, baldin eta Administrazio Publikoek eurek, beraien beharkizunen baitan, bete ezin badituzte-. F) puntuak ere kooperatibak lotzen ditu, goi-kargu eta arduradun nagusien urteko ordainsariak eta kargua uzteagatiko kalte-ordainak argitaratzea exijituz, baina gainontzeko paragrafoetako kasuek ez, gaia dela eta.

Aurreko guztia aintzatetsiz, ezinbesteko deritzot atal hau aztergai ditudan entitateei nola edo hala eragiten dieten aipatu xedapenen erregelamenduzko garapenaren premia abertituz amaitzea. Izan ere, bai kooperatibek, bai publikoak ez diren bestelako erakundeek, 19/2013 Legearen aplikazio-eremu subjektiboan izandako sarrera azeleratuak beren kokatzearen egokieraren inguruko eztabaida pitzaraztea espero da, azaldutakoa horren interpretazio posible bat baino izan ez delarik. Bien bitartean, legegile autonomiko batzuk urrats bat gehiago ematen saiatu dira.

\section{b) Autonomia Erkidego mailakoak: Estatuko Legeaz haratago}

Abenduaren 10etik aurrera, aztertu berri dudan 19/2013 Legearen betebeharrak bazterrezinak izango dira, orduantxe bukatuko baita bere azken xedapenetako bederatzigarrenak Autonomia Erkidegoen eta Toki-erakundeen egokitzapenerako emandako gehienezko bi urteko epea. Dena den, tarte hori albo batera utzita, Autonomia Erkidego ia denek dagoeneko euren gardentasun lege propioa aurkeztu dutela esan beharra dago edo prozesu horretan abantzatuta daudela behintzat. Horietako batzuk, aitzindu moduan, espainiar legegileak ezarritako gutxienekoa betetzera mugatu gabe, berori garatzen ahalegindu dira, baita beraien aburuz dituen akatsak zuzentzen ere, azken hauek, Cotino Huesoren ustez, primerako abagunea direlarik eurentzat ${ }^{14}$.

Ondoko lerroek, testu nazionalaren aurreikuspenak gainditzeaz batera kooperatibak lotzen dituzten manu autonomiko berriak ezaguta-

14 Cotino Hueso, Lorenzo. «El derecho fundamental de acceso a la información del sector público y su reutilización». In: VAlero TORRIJOS, Julián eta FERnÁndez SALMERÓN, Manuel. Régimen jurídico de la transparencia del sector público: Del derecho de acceso a la reutilización de la información. Thomson Reuteurs, Zizur Txikia, 2014, 66. or. 
raziko dituzte beraz, hurrengo atalak landuko duen Euskal Sektore Publikoaren Gardentasunaren, Herritarren Parte-hartzearen eta Gobernu Onaren Lege Proiektuaren edukiarekin ${ }^{15}$ aldaratzeko.

Andaluziako Gardentasun Publikoaren Legeak ${ }^{16}$, kasu, bere Zioen Azalpenaren arabera, «Estatuko oinarrizko araudiaren garapena du helburu[...], ahal den neurrian gardentasunaren menpeko jardueraesparruaren zabaltzean sakonduz». Alabaina, kooperatiba andaluziarrek publiko egin beharreko informazioaren handitze horren efektuak ikustatu baino lehen, nabarmentzekoa da beren posizioa zehaztea ere lortu duela Legeak. Preseski, bere aplikazio-eremu subjektiboak kooperatibak barne hartzen dituela ulertzeko 19/2013 Legeak erabiltzen dituen konexio-puntuekin bat egin duela egia den arren, 5.1. artikuluko bigarren puntuan zera argitu du: kondizio horiez landa, euren aktibitate eta funtzionamendu arruntaren finantziaziorako sarbidea Andaluziako Juntaren aurrekontuetako subentzio eta laguntzen bidezkoa denean, publizitate-eskakizun espezifikoen menpe ere jarri ahal izango dituela, publizitate aktiboaren alorrean jasotzen dituen gardentasun irizpide analogoak aplikatuz —eta beraien izaera eta aitortutako xedeak errespetatuz, betiere-. Eta ez hori bakarrik, Estatuko Legeak ez bezala, bere VI. Tituluan zehapen-araubide bat jaso baitu, organismo hauei, bai subentzio edo laguntza publikoen hartzaile gisa, bai kontratista gisa, erantzukizuna eskatzen diena.

Hori esanda, legegile andaluziarrak publizitate aktiboaren betebeharretan zorrotzagoa izan nahi izan du. Eta baita lortu ere, Estatuko Legeak lerrokatutako informazioa xehatu ez ezik, ugaritu egin baitu 10-16. artikuluetan, 17.ean herritarren interesekoa izan daitekeen beste edozein informazio baitaratzeko aukera eman duelarik gainera. Zentzu horretan, eta kooperatibei begira, argitaratu beharreko erakunde- eta plangintza-informazioaren hedapena da aipagarriena: kontakturako datuak —egoitza, telefonoa eta helbide elektronikoa-; lanpostuen harreman eta katalogoak, urteko ordainsariak adieraziz; lan-baldintzen hitzarmen arautzaileak; etab.

Era berean, Gardentasunaren eta Informazio Publikorako Sarbidearen inguruko 2/2014 Lege kanariarra, abenduaren 26koa ${ }^{17}$, subentzio eta laguntza publikoen onuradunei eragiteko Estatuko Legeak finka-

15 Ikus: http://ht.ly/UtOrj (Azken kontsulta, 2015eko azaroaren 16an).

16 Andaluzia. 1/2014 Legea, ekainaren 24koa, Andaluziako Gardentasun Publikoari buruzkoa. Andaluziako Juntaren Aldizkari Ofiziala, 2014ko ekainaren 30a, 124. zk., 10. or.

17 Kanariak. 12/2014 Legea, abenduaren 26koa, Gardentasunaren eta Informazio Publikorako Sarbidearen ingurukoa. Kanarietako Aldizkari Ofiziala, 2015eko urtarrilaren 9a, 5. zk., 958. or. 
tutako irizpideen zenbatekoak murrizteagatik gailentzen da: Kanarietako Autonomia Erkidegoko Aurrekontuen karguko 60.000 eurotik gorako subentzio edo laguntzak eskuratzea edo gutxienez urteko sarreren \%30a halakoa izatea, 5.000 euroko minimoarekin. Halere, azpimarratzekoa da Asturiasko Printzerriko Gardentasunaren Lege Proiektuak $^{18}$ kopuru horiek areago jaistea aurreikusten duela: 50.000 eurotik gorakoa, lehenengoa, eta gutxienez \%40a, bigarrena, 3.000 euroko minimoarekin. Gainerakoan, Autonomia Erkidego bi-biek, Andaluziakoak egin legez, publizitate aktiboko obligazioak gogortu dituztela eta hauen betepenaren bermerako arau-hauste eta zehapenen erregulazio zehatza gorpuztu dutela agertu daiteke.

Beste nobedade garrantzitsu bat pasadan abenduaren 29an baietsitako Gardentasun, Informazio Publikorako Sarbide eta Gobernu Onaren 19/2014 Lege katalanak dakar ${ }^{19}$. Hain zuzen ere, interes orokorreko zerbitzutzat hartutako jarduerak gauzatzen dituzten pertsona fisiko eta juridikoak, alde batetik, eta interes taldeak, bestetik, bere aplikazio-esparru subjektiboan sartu ditu. Horrek zer suposatzen du? Arestian aipatutako kasuei, interes unibertsaleko zerbitzuen ematean kolaboratzea edo lobbynga eginez ${ }^{20}$ aktore sozialaren papera betetzea batzen zaizkiela Kataluniako kooperatibak Legearen menpe daudela ondorioztatzeko orduan.

Eta azkenik, baitezpadakoa da orain arteko gardentasunaren arau autonomiko egokienak, hots, aurten, martxoaren 25ean, aho batez onartutako Aragoiko Jarduera Publikoaren Gardentasunari eta Herritarren Parte-hartzeari buruzko 8/2015 Legeak21, arlo honetan dakartzan eta adierazitakoez bestelakoak diren berrikuntzei erreferentzia egitea, askotxo izan ez arren.

Bada, bere Hitzaurreak azaltzen duenez, «Legearen helburua Estatuko oinarrizko arauak gardentasunaren esparruan jasotako betebeharrak garatu, osatu eta handitzean datza, baita herritarrei aitortutako

18 Ikus: http://www.asturias.es/webasturias/GOBIERNO/TRANSPARENCIA/proyecto_ ley_transparencia .pdf (Azken kontsulta, 2015eko azaroaren 16an).

19 Katalunia. 19/2014 Legea, abenduaren 29koa, Gardentasun, Informazio Publikorako Sarbide eta Gobernu Onarena. Kataluniako Generalitatearen Aldizkari Ofiziala, 2014ko abenduaren 31a, 6780. zk., 9. or.

20 Legearen 2.g) artikuluko definizioarekin bat, horrek zera esan nahi du: politika publikoetan edo erabakiak hartzeko prozesuetan modu aktiboan parte hartzea, hauen orientazioan eragina izateko xedearekin interes propio bat, hirugarrenena edo orokorra defendatuz.

21 Aragoi. 8/2015 Legea, martxoaren 25ekoa, Jarduera Publikoaren Gardentasunari eta Herritarren Parte-hartzeari buruzkoa. Aragoiko Aldizkari Ofiziala, 2015eko apirilaren 4a, 68. zk., 11305. or. 
eskubideen eraginkortasuna bermatuko duten mekanismoen ezarpenean ere». Eta berori gaindika erdietsi duela esan daiteke, urtarrilaren 10etik aurrera ${ }^{22}$ Aragoiko Administrazio Publikoko zoko ia guztiak besarkatuko dituen paradigma garden, parte-hartzaile eta erantzule baten alde egin baitu, tinko. Baina beste sektoreetako agenteei begira, informazioa emateko obligazioa bakarrik ondu du zertxobait, adjudikaziodunen betebeharrak administrazio-klausula partikularren pleguan eta subentzioen hartzaileenak emakidaren oinarri erregulatzaile, erresoluzio edo hitzarmen arautzailean zehaztea eskatu duelarik. Hori bai, Administrazio Publikoekin egindako kontratu (16. art) eta hitzarmenen (17. art) inguruan eman beharreko informazioan nabarmen sakondu du. Interpretazioak saihestekotan ${ }^{23}$, gainera, Administrazio Publikoen konturako aktibitateen negozio bolumenak enpresaren bolumenaren \%40a gainditzen duenean zuzendaritza-kargudunek jasotako ordainsariak argitaratzea exijitu die, espresuki.

Horiek horrela, aipatu Autonomia Erkidegoek berriki aurkeztutako gardentasunaren babes eta sustapenerako arau-estrategiek lan honek ardatz dituen entitateak Estatuak baino modu konkretuago batean integratu dituztela ondorioztatu daiteke. Ondorengo atalak esplikatuko du Euskal Autonomia Erkidegoak bide bera jarraitu duen ala ez.

\section{Kooperatiben gardentasun publikoa sendotzeko zenbait euskal ekimen}

a) Euskal Sektore Publikoaren Gardentasunaren, Herritarren

Parte-hartzearen eta Gobernu Onaren Lege Proiektua

Azaroaren 10ean gobernamendu onaren euskarrietatik abiatuz euskal sektore publikoaren modernizazioa eraikitzeko lege proiektu bi onartu zituen Eusko Jaurlaritzak: Euskal Sektore Publikoaren Gardentasunaren, Herritarren Parte-hartzearen eta Gobernu Onaren Lege Proiektua eta Euskal Sektore Publikoaren Antolamendu eta Funtzionamen-

22 Bere azken xedapenetako hirugarrena eta xedapen gehigarrietako lehenengoa aintzatetsiz, sarbide eskubideari buruzko manuen edukia uztailaren 10az geroztik, hots, bere argitalpenetik hiru hilabete pasatuta Legea indarrean sartu zenetik, eskatzeko modukoa bada ere, publizitate aktiboko betebeharren betepenerako sei hilabeteko epea dago.

23 Gogoan eduki Estatuko Legearen 8.1.f) artikuluak kooperatibak lotzen dituela esandakoan, jorratzen duen gaia dela eta ateratako ondorio bat baino ez dela adierazi. 
duaren Lege Proiektua. Testu bi-biak, debate parlamentariorako Eusko Legebiltzarrera igorri direnak orain, herritarren egungo beharrizanak eraginkortasunez aseko dituen kalitatezko euskal zerbitzu publiko baten finkapenean funtsezko papera betetzera datozela esan daiteke. Alabaina, ezin da alboratu euskal kooperatibek, beren izaera solidario, konprometitu eta parte-hartzailea medio, prozesu horri egin diezaioketen ekarpena. Bada, kooperatiben tasun bereizgarri horiei gardentasun publikoa gaineratzeko xedeaz, aipatu ekimenetatik lehenengoak zenbait nobedade jaso ditu.

Bere Zioen Azalpenak aurreratzen duenez, Lege Proiektuak puntu gehientsuenetan oinarrizko legeriaren eskema bera jarraitu duen arren, «Euskal Autonomia Erkidegoaren esparruan 19/2013 Legearen oinarrizko edukia garatzen du». Horrela, bere aplikazio-eremu subjektiboari dagokionean, adibidez, euskal sektore publikoa osatzen duten entitateak ez ezik, pribatuak edota partikularrak direnak ere lotzen dituela azaldu du bere 3. artikuluan, egoera jakinetan bada ere: «euskal sektore publikoarekin duten harremanean edo beren izaera juridikoa, finantziazio maila, funtzio publikoen gauzatzea edo zerbitzu publikoen prestazioa dela eta». 19. artikuluan zehaztu ditu, hain justu, informazioa helarazteko obligazioa duten eta publikoak ez diren subjektu horiek, eta Estatuko Legearekin erkatuz, nahiz eta erabilitako irizpideak igualak izan, irakaskuntza kontzertatuko zentroak, batetik, eta presio- edo interes-taldeak, bestetik, baitaratu ditu. Euskal kooperatibak, beraz, ondorengo kasuetan egongo dira arauaren manupean: ekitaldiko aurrekontuen karguko 100.000 eurotik gorako subentzio edo laguntza publikoak jasotzen dituztenean, edo gutxienez beren urteko sarreren \%40a halakoa denean, 5.000 euroko minimoarekin (19.1.b. art); irakaskuntza kooperatibak izan eta natura kontzertatua dutenean — kontutan eduki gehienak halakoak direla(19.1.c. art); lobbyinga egiten dutenean, «herritarren parte-hartze eta kolaboraziorako eta Euskal Autonomia Erkidegoaren interes ezberdinen ordezkaritza-taldeen Erregistroan, edo honekin modu koordinatuan funtzionatzen duten bestelakoetan inskribatuta badaude, betiere» (19.1.d. art); eta norberaren edo inoren kontura zerbitzu publikoak eman edo administrazio-ahalak egikaritzen dituztenean, kontratistak direnean barne (art. 19.2).

Behin betiko testua onartu aurretik, lehen kasuko zenbatekoak murriztu beharko lirateke, Kanariak etsenplutzat hartuta. Eta zergatik ez, gainontzeko subjektu obligaziodunen posizioarekin parekatuz, publizitate aktiboko betebeharrez haratago joateko aukera balioetsi ere, Euskadiko Ekonomia eta Gizarte Arazoetako Batzordea, Lege Aurreproiektuari buruzko bere 12/15 Irizpenean, kostuak eta konfiden- 
tzialtasuna argudiatuz, horren kontra agertuagatik ${ }^{24}$. Izan ere, informazio publikorako sarbide eskubidearen baitan herritarrek eskatutako informazioa helarazteko betebeharrak dakartzan kostuen ideia horri gardentasun korporatiboan inbertitzearena gailendu egiten zaiola deritzot. Eta ezin ahantzi daiteke enpresa- zein pertsona-datuak babesten dituen konfidentzialtasunaren printzipio orokorraren eta gardentasunaren arteko oreka lortzeko neurriak hartu dituela legegileak, aipatu eskubidearen muga, aldi baterako irismen eta salbuespenak (38 eta 39. art), egikaritza partziala (40. art), eta ponderazio irizpideak (41. art), esaterako.

Edozein kasutan, ontzat eman behar da Lege Proiektuak subjektu hauek modu aktiboan argitaratu beharreko informazioa pixka bat zabaldu izana. Hasteko, garrantzi juridikoa duen informazioari buruzko 26. artikuluak, jabari publikoan edo zerbitzu publikoen kudeaketan eragina izan dezaketen baimen, deklarazio erantzule eta aurretiko komunikazioak argitaratzeko zeregina ezarri die. Hurrena, 27. artikuluak, intzidentzia ekonomikodun administrazio jardueraren inguruko informazioa zehazten duenak, emakida bidez zerbitzu publikoen prestazioaz arduratzen diren horiek, herritarrek euren bizi-kalitate egokiaren edo eskubideen kautan eskatutako informazioa bermatzera derrigortu ditu. Eta bukatzeko, 31. artikuluak, interes orokorreko informaziotzat joz, zerbitzu publikoetara sarbidea izateko betekizun eta kondizioak publikatzera, ordutegiak, exijitutako tasa, tarifa eta prezioak, eta itxarote zerrendak erantsiz.

Horrez aparte, III. Tituluko IV. Kapituluan, beste Autonomia Erkidego batzuei jarraiki, erregimen zehatzaile irmo bat jaso duela ohartarazi beharra dago.

Baina atal hau amaitu baino lehen, Eusko Jaurlaritzak adostasun faltagatik bertan behera utzitako eta Euskal Sektore Publikoaren Antolamendu eta Funtzionamenduaren Lege Proiektuaren berehalako aurrekaria den Euskal Administrazio Publikoaren Lege Proiektua ${ }^{25}$ hartu nahiko nuke ahotan. Zergatik? Bere IV. Titulua Euskal Autonomia Erkidegoan 19/2013 Legearen funtsezko edukia garatzeko lehenbizi hartutako bidea izan zelako.

24 Ikus: http://www.cesegab.com/Portals/0/Libros/D15-13\%20lrizpena_12.pdf (Azken kontsulta, azaroa-ren 18an).

25 Ikus: http://www.izenpe.com/s15-4812/es/contenidos/plan_programa_proyecto/ xleg_pyley_05/adjuntos /Ley\%20de\%201a\%20AP\%20vasca\%20eu_TEXTO\%20APROBADO.pdf (Azken kontsulta, azaroaren 18an). 
b) Gipuzkoa eta Bizkaiko Aldundien gardentasunaren foru arau berriak: aipamen laburra

Foru Aldundien esparrura salto eginez gero, 2014ko otsailaren 6ko 4/2014 Foru Araua, gardentasunari eta informazio publikoa eskuratzeari buruzkoa ${ }^{26}$, Gipuzkoan, eta Gardentasuneko Foru Arauaren Proiektua27, Bizkaian, aurkituko ditugu. Arabako Aldundiak, aldiz, ez du oraindik gardentasunaren inguruko araurik prestatu, nahiz eta horretarako intentzioa agertu eta pasadan irailaren 3an Etika eta Gobernu Onaren Kodea onartu zuen.

Hori esanda, azpimarratzekoa da lehenengoak Gipuzkoakoa Dyntraren Rankingean Aldundirik gardenena izateko zutoin moduan jokatu duela ${ }^{28}$. Halarik ere, lan honen gaiari dagokionean, ez du ekarpen handirik jaso, entitate publikoei zuzendu baitzaie, nagusiki.

Bigarrenak bai, bere aplikazio-eremuan barne hartu ditu erakunde pribatuak. Dena den, ez da Estatuko Legearen aurreikuspenetatik askorik urrundu. Legegile bizkaitarra garaiz dabil, baina, kooperatibek, eta, oro har, ekonomia sozialak, Lurralde Historiko honetan duten garrantzia aintzatetsi eta beren izaera juridikoak zein printzipio gidariek sostengatuko luketen manu espezifiko bat aurkezteko.

\section{c) Gardentasunak egungo kooperatiba-legerian duen tokiaren gogoeta}

Aurreko ataletako arauen baitan publikoak ez diren erakundeek duten kokapen konkretua erregelamenduzko garapenak edota interpretazio judizialak —edo, hala bada, gardentasunaren babes eta kontrolerako organo berriak bere ebazpenetan egindakoak - argitzea espero da. Artean, lagungarria izan daiteke, lan honi dagokionean, kooperatiben legedi berezituak gardentasunari zein paper eskaini dion ikustatzea.

Bada, Euskal Kooperatiben 4/1993 Legeak, ekainaren 24koak29, «kooperatibismo eraginkor, demokratiko eta gardenean hezurmami-

26 Gipuzkoa. 4/2014 Foru Araua, otsailaren 6koa, gardentasunari eta informazio publikoa eskuratzeari buruzkoa. Gipuzkoako Aldizkari Ofiziala, 2014ko otsailaren 10a, 26. zk., 2. or.

27 Ikus: http://www.bizkaia.net/home2/Archivos/DPTO7/Noticias/Pdf/GARDENTASUNEKO\%20FORU \%20ARAUA\%20NORMA\%FORAL\%20TRANSPARENCIA. pdf?idioma=EU (Azken kontsulta, azaroa-ren 19an).

28 Ikus: http://dyntra.org/diputaciones-cabildos-y-consejos-insulares/ (Azken kontsulta, azaroaren 19an).

29 Euskadi. 4/1993 Legea, ekainaren 24koa, Euskal Kooperatibena. Euskal Herriko Aldizkari Ofiziala, 1993ko uztailaren 19a, 135. zk., 6863. or. 
tzen» zela azpimarratu zuen bere Erabaki Orokorretan. Nahiz eta ondoren berariazko gardentasun-eginbeharrik jaso ez zuen, garrantzitsua da garai hartan, jada, gardentasuna kooperatiben izatearen elementu nagusien artean jarri izana. Jakina da, gainera, Eusko Jaurlaritza esparru honetan lege berri bat egitekotan dela. Zer proposatu? Kooperatibei euren antolamendu zein jardutea gardenak izatea galdatzen dien betebehar orokor bati erreferentzia egiteaz haratago joan eta Euskal Sektore Publikoaren Gardentasunaren, Herritarren Parte-hartzearen eta Gobernu Onaren Legearen hariari jarraipena eta egokitzapena emango lizkiokeen sail bat barne hartzea.

Zentzu horretan, Euskadiko Hirugarren Sektore Sozialeko Legearen Proiektuak ${ }^{30}$, adibidez, Administrazio Publikoekin kooperatzerako eta kolaboratzerako orduan zertu beharreko praktiken inguruko zenbait obligazio ezarri dizkie Euskadiko Hirugarren Sektore Soziala osatzen duten erakundeei, kudeaketa etiko eta garden bat segurtatu eta gizarteak eurengan duen konfiantza mantendu eta indartzeko xedeaz. Zehatzago, bere 17. artikuluan, "erantzukizun publikoko zerbitzu sozialen horniduraz arduratzerakoan edo interes orokorreko bestelako aktibitateetan parte-hartzerakoan» barnera zein kanpora begira gardenak izateko eta kontuak emateko beharkizuna ipini die, baita gestioeredu demokratiko bat agertzekoa ere. Nabarmentzekoa da, bestela, sektorearen promoziorako estrategian ere azaltzen dela gardentasunaren ideia, Eusko Jaurlaritzari aldeko ekimenak martxan jartzea eskatuz.

Herri onurako kooperatibek pisu partikularra dute testuinguru honetan. Erakunde hauek aipatu Euskal Kooperatiben Legearen 137.2. artikuluak ezagutarazi zituen lehenengoz: «Beren funtzioen gauzatzearekin Euskadiren interes orokorraren promozioa faboratzen duten entitate kooperatiboak herri onurako moduan aitortuko ditu Eusko Jaurlaritzak arauz manatutako prozedura, erregimen eta baldintzei jarraiki». Azken hauek 64/1999 Dekretuak ${ }^{31}$ erregulatu zituen, zehazki. Testuaren hasieran, baina, Eusko Jaurlaritzaren Justizia, Lan eta Gizarte Segurantza Sailak, zera seinalatu nahi izan zuen: "Agerikoa da[...]kooperatibasozietate bati herri onurako izaera aintzatestea oso baliabide aparta gerta dakiokeela bere bilakaerarako, erakundeen laguntza eta babesa jasotzeko, eta horrekin, mugimendu kooperatibistak bazkideei ez ezik

30 Ikus: https://www.euskadi.eus/contenidos/noticia/info_proyectoleytercersector/ eu_doc/adjuntos/2\%C2 \%BA\%20VERSION\%20SEPTIEMBRE\%20LEY\%20DEL\%20TERCER\%20SECTOR\%SOCIAL.pdf (Azken kontsulta, azaroaren 19an).

31 Euskadi. 64/1999 Dekretua, otsailaren 2koa, herri onurako kooperatiba-sozietateei dagozkien prozeduren eta betekizunen araudia onartzeko dena. Euskal Herriko Aldizkari Ofiziala, 1999ko otsailaren 17a, 33. zk., 2910. or. 
oro har gizarteari ere eskaintzen dion zerbitzurako». Eta hain justu, subentzioak beren finantziazio iturri nagusia izateak, erakunde hauek, interes taldeei, eta guztiz gain, Administrazio Publikoari, informazioa helarazteak duen inportantziaren inguruko uste osoa izatera areago behartzen dituela pentsaraztera garamatza, eta, halaber, eman beharreko informazio hori kalitatezkoa izan dadin eginahal gehiago egitera. Herri onurako kooperatibek gardenak izateko ardura manifestuagoa dutela, azken finean.

Esanak esan, lege-ekimen guzti hauen bitartez egindako esfortzua euskal kooperatibek eurek martxan jarritako ekintzek osatu beharko dute, horixe. Gardentasun publikoaren aldeko konpromiso erreala, sustatua izanagatik ere, berezko konbentzimendutik eratorriko baita beti.

\section{Euskal kooperatiben gardentasun publikoarekiko konpromisoaren garrantzia}

Momentuz suposatzen zaizkien betebehar materialei erantzuna eman ez ezik, euskal kooperatibek, motu proprio eta ahal duten neurrian, publizitate aktiboko gainontzeko obligazioak ere euren gain hartu beharko lituzkete. Gardentasunak beren funtzionamendu onean zein herritarrekiko tratuaren bilakaera egokian jokatzen duen paperari dagokion inportantzia aitortzen diotela azaltzen hasteko modu aproposa izango litzateke hori, zinez.

Baina arau-inposizioez haratago, gardentasunari behar bezalako babesa emateak organismo hauen baitan berme eta sustapen neurri ezberdinak aktibatzea ere galdatzen du. Izan ere, LARRAÑAGA ELORZAK abertitu bezala, «legalki jardun izanagatik, gardentasunaren helburuak ez betetzea gerta daiteke» ${ }^{32}$.

Bada, ebaluazio eta kontrolari dagokionean, entitate hauek, eskura dituzten azterlan-erremintez baliatuz (auditoria ekonomikoak, egiaztapenak, etab.) eta euren gobernu-organoek alor honetan egiten duten lanarekin batera, beraien aritzea ezagutarazi beharko lukete, bai barrura, bai kanpora, begira33. Horretarako, esaterako, lan taldeak eratu

32 Larrañaga Elorza, Ainhoa. «La transparencia en las cooperativas: más transparencia es más participación». Nueva Época, 16. zk., 2014, 86.or.

33 Izan ere, gardentasuna bi ikuspegitatik aztertu daiteke. Kanpo-dimentsioan, entitateei zilegitasun soziala ematen dien balorea da, bizirik irauteko kondizioa. Erakundearteko bikaintasunari estuki lotua eta kalitatearen sinonimo, sektorea garatu eta sare eta kolaborazioak sortzea ahalbidetzen du. Barne-dimentsioan, ostera, bi mailatan kontenplatzen da, entitatearen funtzionamendua inspiratzen duen zeharkako balore moduan, 
eta agentzia kalifikatzaileen zerbitzuak aprobetxatu ditzakete, hurrenez hurren. Kode etikoen elaborazio eta jarraipena ere onuragarria izango litzateke, borondatezko instrumentuak izanagatik, kooperatibismoaren baloreekin koherenteak diren praktikak gauzatzearen kontzientzia agertzea ahalbideratzen baitute, erreferentzia-marko bat eskainiz ${ }^{34}$.

Gardentasunaren promozioan, bestalde, komunikazio-estrategiek dute giltza, inongo zalantzarik gabe. HERRANZ DE LA CASAren hitzetan, «adibide gisa bakarrik balio dezala organizazio batek kanpo-inguruarekin komunikazio eraginkor bat lortzen ez badu, bere produktu edo zerbitzuak eskuratu edo kontsumitzeko, edo bere ideiak konpartitzeko, bezero edo erabiltzaile potentzialak gogatzea zailago izango duela», barne-inguruan falta badu, enplegatuak eurak efizientziaz eta efikaziaz parte-hartzeko eta lan egiteko konbentzitu eta motibatzea gaitzago izango duen legez ${ }^{35}$.

Abantailak, bereziki, Interneten tokitzeak dakartza, web orrialdeen bitartez informazio esanguratsu bezain argia argitaratuz, betiere. Zentzu horretan, urteko aktibitateen balantzea eta balorazioa jasotzen dituen memoria, batetik, eta aldizkariak, informazio-zirkularrak eta antzekoak, bestetik, formatu elektronikoan helarazteak aukerakoa dirudi. Aldi berean egitura eta prozedura modernizatu eta sinplifikatuak aurkezteko premia azpimarratu behar da ordea, emandako zerbitzuen prestazioaren kalitatea handitzeaz gain, interesatuekiko erlazioak tinkatu baititzake. Hori bai, kooperatibak sarean kokatzeko orduan, beren tamaina eta bitartekoak oztopo izan daitezke, euren arteko konexio eta kolaborazioarekin gainditu ahal izango dituztenak oro har.

Horiek horrela, nahitaezkoa da aipatu bultzatze formuletara eta antzekoetara jotzea gardentasun nozioaren eta kooperatiben gardentasunaren artean artikulazio-gradu desiratua lortzeko, hots, entitate hauek sortuak izan ziren misioa betetzen dutela bermatzen duen mailara iris-

batetik, eta bere kudeaketa-prozesuarekin erlazionatutako maila funtzionaleko balore taktiko-operatibo bezala, bestetik. RuIz LozAno, Mercedes, TIRAdo ValenCIA, Pilar eta MoRALES GUTIÉRREZ, Alfonso Carlos. «Transparencia y calidad de la información económicofinanciera en las entidades no lucrativas. Un estudio empírico a nivel andaluz». CIRIECEspaña, Revista de economía pública, social y cooperativa, 63. zk., 2008, 257. or.

34 Gai honetan sakontzeko, ikus, adibidez: Longinos MARín RIVES, Joaquín, ArCAS LARIO, Narciso, MARTínez LeÓN, Inocencia María eta Olmedo Cifuentes, Isabel. «Transparencia, gobierno corporativo y participación: claves para la implantación de un código de conducta en empresas de economía social». Revesco, Revista de Estudios Cooperativos, 108. zk., 2012, 86-112. or.

35 HeRranz de LA CASA, Jose María. «La comunicación en las organizaciones de la economía social». In: HeRRANZ DE LA CASA, Jose María eta SAlINAS Ramos, Francisco (Koord.). Empresas de Economía Social: aspectos para su desarrollo. Publicaciones Universidad Católica de Ávila, Avila, 2007, 78. or. 
teko. Kooperatiba garden batzuen talde-lanak baino ezin baitezake eratu, hala merkatuak, nola Estatuak, azkenaldian bizi dugun krisiaren aurrean erakutsitako erreakzionatzeko ezinaren alternatiba. Jokabide justu, solidario eta erantzule bat islatzeak, afera horretan esku hartzeko kooperatibek dituzten gaitasun hobeen errekonozimendu publikoa suposa baitezake, aldi berean kontribuzio eta finantziazio pribatuko bide berrien sorburu bilaka daitekeena, eta garrantzitsuena dena, sektorearen indartzera bideratutako pizgarriak emango dituzten politika publikoak erreklamatzen dituen herritarren eskakizun irmo.

Amaitzeko, baina, ezin ahantzi daiteke gardentasunaren eta etikaren arteko lotura estua, guztion ongiaren bilaketan gardentasuna lehenesten duen etika baten berrezarpenaren ideia protagonismo gorakor bat eskuratzen ari den honetan. Erakundeek, publiko, pribatu zein erdibidekoek, euren arteko elkarrekintzan zein herritarrekin dituzten harremanetan, irekiera demokratikoa gailendu behar baitute ezinbestez, praktika gardenak errespetuzko jarrera baten isla diren bezala, errespetuak berak sinesgarritasuna eta konfiantza merezi ditu eta.

\section{Bibliografia}

Blanes Climent, Miguel Ángel. La transparencia informativa de las Administraciones Públicas. El derecho de las personas a saber y la obligación de difundir información pública de forma activa. Thomson Reuteurs, Zizur Txikia, 2014.

Cotino Hueso, Lorenzo. «El derecho fundamental de acceso a la información del sector público y su reutilización». In: VALERO TORRIJOs, Julián eta FernánDEZ SALMERÓn, Manuel. Régimen jurídico de la transparencia del sector público: Del derecho de acceso a la reutilización de la información. Thomson Reuteurs, Zizur Txikia, 2014, 37-72. or.

Euskadiko Ekonomia eta Gizarte Arazoetako Batzordea. Euskal Sektore Publikoaren Gardentasunaren, Herritarren Parte-hartzearen eta Gobernu Onaren Lege Aurreproiektuari buruzko 12/15 Irizpena: http://www.cesegab.com/ Portals/0/Libros/ D15-13\%20lrizpena_12.pdf

FAJARDo GARCíA, Isabel-Gemma. "La especificidad de las sociedades cooperativas frente a las sociedades mercantiles y la legitimidad de su particular régimen jurídico y fiscal según el Tribunal de Justicia de la Unión Europea». Revista de Derecho Mercantil, 288. zk., 2013, 189-222. or.

FeRnÁndez RAmos, Severiano. "El ámbito subjetivo de la normativa sobre transparencia del sector público. Problemas y disfunciones». In: Valero TorRIJOS, Julián eta Fernández Salmerón, Manuel (Koord.). Régimen jurídico de la transparencia del sector público. Del derecho de acceso a la reutilización de la información. Thomson Reuteurs, Zizur Txikia, 2014, 105-134. or 
FERnÁndez RAmos, Severiano. "Transparencia y Acceso a la Información Pública». In: Fernández RAmos, Severiano eta Pérez Monguió, José María, Transparencia, Acceso a la Información Pública y Buen Gobierno. Ley 19/2013, de 9 de diciembre. Thomson Reuteurs, Zizur Txikia, 2014, 17-293. or.

GADEA SOlER, Enrique. «Difusión de valores y principios cooperativos entre los jóvenes». In: ArnÁEz ArCE, Vega María (Coord.). Difusión de los valores y principios cooperativos entre la juventud. Dykinson, Madril, 2015, 135-149. or.

Guichot ReInA, Emilio. Transparencia y Buen Gobierno. Estudio y Ley. Thomson Reuteurs, Zizur Txikia, 2014.

HerRanz de la CASA, Jose María. «La comunicación en las organizaciones de la economía social». In: HeRranz de LA CASA, Jose María eta Salinas RAMOS, Francisco (Koord.). Empresas de Economía Social: aspectos para su desarroIlo. Publicaciones Universidad Católica de Ávila, Avila, 2007, 61-96. or.

LARRAÑAGA ElorZA, Ainhoa. "La transparencia en las cooperativas: más transparencia es más participación». Nueva Época, 16. zk., 2014, 82-95. or.

Olmedo Palacios, M. «La Ley 19/2013, de 9 de diciembre, de transparencia, acceso a la información y buen gobierno». Diario La Ley, 8237. zk., 2014, 1-15. or.

Ruiz lozano, Mercedes, Tirado Valencia, Pilar eta Morales Gutiérrez, Alfonso Carlos. "Transparencia y calidad de la información económico-financiera en las entidades no lucrativas. Un estudio empírico a nivel andaluz». CIRIEC-España, Revista de economía pública, social y cooperativa, 63. zk., 2008, 253-274. or.

\section{Legeria iturriak}

Espainia. 19/2013 Legea, abenduaren 9koa, gardentasunari, informazio publikoa eskuratzeko bideari eta gobernu onari buruzkoa. Estatuko Aldizkari Ofiziala, 2013ko abenduaren 10a, 295. zk.aren euskarazko gehigarria, I. at., 1. or.

Euskadi. 4/1993 Legea, ekainaren 24koa, Euskal Kooperatibena. Euskal Herriko Aldizkari Ofiziala, 1993ko uztailaren 19a, 135. zk., 6863. or

Andaluzia. 1/2014 Legea, ekainaren 24koa, Andaluziako Gardentasun Publikoari buruzkoa. Andaluziako Juntaren Aldizkari Ofiziala, 2014ko ekainaren 30a, 124. zk., 10. or.

Kanariak. 12/2014 Legea, abenduaren 26koa, Gardentasunaren eta Informazio Publikorako Sarbidearen ingurukoa. Kanarietako Aldizkari Ofiziala, 2015eko urtarrilaren 9a, 5. zk., 958. or.

Katalunia. 19/2014 Legea, abenduaren 29koa, Gardentasun, Informazio Publikorako Sarbide eta Gobernu Onarena. Kataluniako Generalitatearen Aldizkari Ofiziala, 2014ko abenduaren 31a, 6780. zk., 9. or.

Aragoi. 8/2015 Legea, martxoaren 25ekoa, Jarduera Publikoaren Gardentasunari eta Herritarren Parte-hartzeari buruzkoa. Aragoiko Aldizkari Ofiziala, 2015eko apirilaren 4a, 68. zk., 11305. or. 
Euskal Administrazio Publikoaren Lege Proiektua: http://www.izenpe.com/ s15-4812 /es/contenidos/plan_programa_proyecto/xleg_pyley_05/adjuntos/ Ley\%20de\%201a\%20AP\%20vasca\%20eu_TEXTO\%20APROBADO.pdf

Asturiasko Printzerriko Gardentasunaren Lege Proiektua: http://www.asturias. es/web asturias/GOBIERNO/TRANSPARENCIA/proyecto_ley_transparencia. pdf

Euskadiko Hirugarren Sektore Sozialeko Legearen Proiektua: https://www. euskadi. eus/contenidos/noticia/info_proyectoleytercersector/eu_doc/adjuntos/2\%C2\%BA\%20VERSION\%20SEPTIEMBRE \%20LEY\%20DEL\%20 TERCER\%20SECTOR\%SOCIAL.pdf

Euskal Sektore Publikoaren Gardentasunaren, Herritarren Parte-hartzearen eta Gobernu Onaren Lege Proiektua: http://ht.ly/UtOrj

Gipuzkoa. 4/2014 Foru Araua, otsailaren 6koa, gardentasunari eta informazio publikoa eskuratzeari buruzkoa. Gipuzkoako Aldizkari Ofiziala, 2014ko otsailaren 10a, 26. zk., 2. or.

Bizkaiko Gardentasuneko Foru Arauaren Proiektua: http:///www.bizkaia.net/ home2/ Archivos/DPTO7/Noticias/Pdf/GARDENTASUNEKO\%20FORU\%20 ARAUA\%20NORMA\%FORAL\%20TRANSPARENCIA.pdf?idioma=EU 